International Review of Research in Open and Distributed Learning Volume 18, Number 2

April - 2017

\title{
A Team of Instructors' Use of Social Presence, Teaching Presence, and Attitudinal Dissonance Strategies: An Animal Behaviour and Welfare MOOC
}

\author{
Sunnie Lee Watson, William R. Watson, Shamila Janakiraman, and Jennifer Richardson \\ Purdue University
}

\begin{abstract}
This case study examined a team of instructors' use of social presence, teaching presence, and attitudinal dissonance in a Massive Online Open Course (MOOC) on Animal Behaviour and Welfare (ABW), designed to facilitate attitudinal learning. The study reviewed a team of six instructors' use of social presence and teaching presence by applying the Community of Inquiry (CoI) framework, as well as the establishment of attitudinal dissonance within the announcements and discussion forums. The instructors entered the MOOC as a collaborative facilitation team and created a highly balanced manner of communication and positive atmosphere within the course. The instructional design focused on creating an informative and knowledgeable network of global learners that would agree that animal welfare was a critical social issue in today's society. These course goals and facilitation intentions were demonstrated through a high number of social and teaching presence indicators, with a significant use of all social presence, teaching presence, and attitudinal dissonance categories in evidence. The results present a review of an instructional team's facilitation that focused on shaping attitudes about the topic of animal behaviour and welfare within a MOOC. We conclude by providing insights into instructional design and facilitation of MOOCs in general or attitudinal learning specifically.
\end{abstract}

Keywords: social presence, teaching presence, attitudinal learning, dissonance, MOOC 


\section{Introduction}

With MOOC learner numbers in 2015 almost equaling the number of learners during the prior three years combined (Wexler, 2015), the popularity of MOOCs has significantly increased the availability of higher education by providing opportunities to massive audiences across the globe (Liyanagunawardena, Adams, \& Williams, 2013). MOOCs enable interaction between a variety of learners from diverse backgrounds and free or low cost access to instruction from world-renowned institutions and educators (Dillahunt, Zengguang, \& Teasley, 2014). Given this, MOOCs have been highlighted as an innovation with the potential to disrupt higher education, enabling increased democratization (Carver \& Harrison, 2013; Flynn, 2013).

The massive and global nature of MOOCs make them an interesting platform for promoting learning about topics that contain innate attitudinal components related to social issues or change. Although initial MOOC offerings were primarily in the hard sciences and computer programming courses (Rodriguez, 2012), many are now offered in the social sciences. These courses have dealt with socio-scientific topicssuch as global warming, nutrition and wellness, and peace and diversity-that have a significant focus on attitudinal learning outcomes, in addition to the typical cognitive goals (Watson, Watson, Richardson, \& Loizzo, 2016; Watson, Loizzo, et al., 2016; Kim, Watson, \& Watson, 2016; Watson, Kim, \& Watson, 2016; Watson \& Kim, 2016). Despite the burgeoning interest in MOOCs, little research exists that focuses specifically on the facilitation strategies of MOOC instructors (Liyanagunawardena et al., 2013), especially facilitation for promoting attitudinal learning (Watson, Watson, Richardson, et al., 2016; Watson, Loizzo, et al., 2016).

Using the CoI framework, this study reviews a team of six collaborative instructors' use of social presence, teaching presence, and attitudinal dissonance within a MOOC on Animal Behaviour and Welfare (ABW) in order to provide insights for effective facilitation approaches for MOOCs and attitudinal learning.

\section{Literature Review}

\section{Social Presence and Teaching Presence}

The CoI framework serves as a process model for assessing socio-constructivist learning environments such as that employed in online learning environments (Garrison, Anderson, \& Archer, 2000). The CoI focuses on the interaction of three components: social presence (SP), teaching presence (TP), and cognitive presence (CP) to help gain insights into online learning environments (Garrison, 2007). SP refers to the interactions between participants, including the instructors and learners, and how they identify with and feel connected in the online environment (Garrison, 2011). Bangert (2008) notes that TP encompasses the strategies that an instructor employs to establish a community of inquiry among the learners. The third component, CP, examines the learners' process of constructing meaning through discussion and reflection (Garrison, Anderson, \& Archer, 2001). Together, these three components 
interact to establish an online collaborative constructivist experience. For the purpose of this study, the CoI framework was applied to examine a team of MOOC instructors' use of social presence and teaching presence by examining course announcements and the team's participation in the discussion forums. While the CoI is not an appropriate lens for all online environments (Rodriguez, 2012), the CoI framework can be leveraged to analyze and understand the interactions in a MOOC designed especially for attitudinal change where learner interaction and collaboration comprise a key component of the instructional design.

Swan, Garrison, and Richardson (2009) define social presence as "the degree to which participants in computer-mediated communication feel affectively connected one to another" (p. 47). Learner interaction is an important component of producing an effective educational environment and is therefore a key consideration when designing for online learning, according to Garrison et al. (2000); and, an effective online learning environment should include affective expression, open communication, and group cohesion (Swan et. al., 2009). Affective expression focuses on establishing a sense of group commitment through peer sharing of attitudes, values, and beliefs. Group cohesion focuses on a group sense of commitment and the focus of learners on common intellectual tasks (Swan, Shea, Richardson, Ice, Garrison, Cleveland-Innes, \& Arbaugh, 2008). Social aspects of learning are critical for the design of effective online courses (Mykota \& Duncan, 2007), and SP likely is important to the delivery of effective attitudinal change instruction.

Swan and colleagues (2008) identify three components of teaching presence: design and organization, facilitating discourse, and direct instruction. Design and organization entails designing the course structure and processes; facilitating discourse is reviewing and commenting on student discussion, as well as managing the discussion and asking questions; and, direct instruction refers to application of the instructor's subject matter expertise through the sharing of that expertise (Anderson, Rourke, Garrison, \& Archer, 2001). Students' perceptions of learning in an online environment are augmented by teaching presence (Morris, 2011; Kanuka, 2011; Shea, Li, \& Pickett, 2006), as are their success rates in online courses (Arbaugh, 2010; Garrison, Cleveland-Innes, \& Fung, 2010; Kupczynski, Ice, Wiesenmayer, \& McCluskey, 2010). Jsksimovic, et al. have demonstrated the importance of SP and TP in helping learners improve academic performance in a traditional online environment. TP not only involves the role of instructors but also learner peers, as students learn from each other's experiences. According to the collaborative constructivist view, which $\mathrm{CoI}$ is founded on, learners learn from the environment and from one another through mutually respectful collaboration as they actively construct and confirm meaning (Swan, Garrison \& Richardson, 2009).

\section{Dissonance for Attitude Change}

Attitude refers to an individual's psychological evaluations about an object, person, or event (Gagne, Briggs, \& Wagner, 1992; Zimbardo \& Leippe, 1991). According to Kamradt \& Kamradt (1999), attitude is comprised of affective, cognitive, and behavioural components. The affective component refers to evaluation based on emotion; the cognitive component refers to evaluation based on knowledge or thoughts; and the behavioural component refers to the actions taken by an individual towards a person, object, or event (Kamradt \& Kamradt, 1999; Simonson, 1979). According to Coleman (2010), attitudes are learned and lead to certain behaviours. They are comprised of affect, behaviour, and beliefs, which are 
subjective facts interpreted by individuals but which may be based on incorrect information. When learners are committed to their beliefs, they are more resistant to attitudinal change, which can make the learning in socio-scientific topics more difficult (Dole \& Sinatra, 1998; Sinatra, Kardash, Taasoobshirazi, \& Lombardi, 2012). This inherent difficulty in negotiating one's beliefs with the realities of new information further illustrate the need to focus on attitudinal learning outcomes in these topics.

Kamradt \& Kamradt (1999) note that instructional strategies targeting attitudinal change involve attempts to produce dissonance or tension within an individual's attitude. In some cases, learners may know about a social problem (cognition), may be affected by it emotionally (affective component), but may not take any action to solve the problem (behavioural component). Here dissonance exists. Instructional strategies designed to bring about attitudinal change, therefore, highlight this dissonance in order to encourage learners to focus on aligning the three attitudinal components.

Instructional strategies can create dissonance or produce an emotional response through the targeting of the affective component of a learner's attitude (Kamradt \& Kamradt, 1999) by using rich media (Simonson \& Maushak, 1996). Similarly instructional strategies involving the presentation of new and credible information that targets the cognitive component of a learner's attitude helps establish a mind receptive to attitudinal change (Bodenhausen \& Gawronski, 2013). To create dissonance in the behavioural component of a learner's attitude, instructors may encourage learners to perform an action that aligns with the desired attitude. Instructors can share personal applications or instances of real world activism to achieve this. Learners may respond by performing the action readily if they are close to acquiring the desired attitude, refuse to act if their attitude is not yet changed, and may attempt the action if the instruction has succeeded in producing the desired attitudinal change (Kamradt \& Kamradt, 1999). Instructional strategies focusing on all three attitudinal components can promote learner dissonance, which often results in attitudinal change.

\section{Effective MOOC Facilitation}

Instructors' effective use of SP and TP has been shown to benefit learners in traditional online environments (Akyol \& Garrison, 2008; Arbaugh \& Hwang, 2006; Hostetter \& Busch, 2013; Joksimović et al., 2015; Richardson \& Swan, 2003; Shea, Li, \& Pickett, 2006) and likely offer insights into improving learning and learner retention in MOOCs. While some MOOCs-specifically AI-Stanford or xMOOCs-are designed to be more instructor-driven, providing a self-paced learning environment with little learner interaction (Rodriguez, 2012), early MOOCs based on a connectionist framework were called c-MOOCs (Liyanagunawardena et al., 2013) and focused on student-driven social networking with little instructor direction (Clarà \& Barberà, 2013).

While little research focuses on the instructional design of effective MOOCs, structuring and facilitating instructional environments involving student interaction and encouraging collaboration and critique among participants has been found to be effective in producing attitudinal change (Kamradt \& Kamradt, 1999; Simonson \& Maushak, 1996). It stands to reason, therefore, that MOOCs focusing on learner interaction and collaboration may likewise hold potential for producing attitudinal change. Furthermore, when learners are publicly asked to demonstrate their new attitudes through collaborative activities, they demonstrate an increase in confidence in the new attitude (Kamradt \& Kamradt, 1999; Simonson, 1979; 
Simonson \& Maushak, 1996).

With the ABW MOOC's goal on facilitating attitudinal learning, this study examines the use of social presence, teaching presence, and dissonance by a collaborative team of instructors in order to gain insights into effective MOOC facilitation and design.

\section{Methods}

\section{Research Design}

We employed a qualitative interpretive research method in order to explore how a team of six MOOC instructors facilitated a MOOC for attitudinal change on the issue of ABW. We explored the instructors' use of SP and TP by applying the CoI framework, and also examined the facilitation of dissonance within the course announcements and discussion forum postings. Our research questions included:

1. How did a MOOC instructor establish social presence with intention to facilitate attitude change around the social issue of ABW?

2. How did a MOOC instructor establish teaching presence with intention to facilitate attitude change around the social issue of ABW?

3. How did a MOOC instructor establish cognitive, affective, and behavioural dissonance with intention to facilitate attitude change around the social issue of ABW?

\section{Description of the Course/ Setting and Participants}

The MOOC was titled Animal Behaviour and Welfare, and was offered by an Applied Animal Behaviour and Animal Welfare program at a Scotland University during fall of 2014 through the Coursera MOOC platform. The researchers had no affiliation with the university offering the course.

The MOOC ran for six weeks and the course objectives included in the online course description were:

- Recognize that animal welfare is complex and involves a number of different disciplines including ethics, science, and law.

- Appreciate that the individual animal's experience is what matters most for its welfare.

- Understand that what we can measure we can manage.

- Explore the way in which small things make a big difference when it comes to an animal's welfare.

A team of six instructors designed and facilitated the course. Each instructor orchestrated the course content and had instrumental roles regarding the videos and discussion facilitation for one or two weeks. 
The MOOC had 22,955 registered learners from 167 countries, ranging from teenagers to students in their late eighties. The 3,043 participants who satisfactorily completed course activities received a certificate of accomplishment. Course instructional materials contained lecture videos, interview videos, academic reading materials, interactive learning materials (created with presentation software Articulate), discussions, and five quizzes, which were the only graded course assignments for formally completing the course. The discussion activity was not graded, but each week contained an open forum for the week's topic. There were no specific questions for the discussions, but the forum prompted the learners to post questions and engage in discussion about that week's topic. For example, one week's discussion forum prompt stated "Use this forum to discuss topics, ask questions, or dive deeper into the materials covered in What is Animal Welfare and Why Does it Matter?"

While we examined all six instructors' facilitation within the MOOC, only three instructors participated in the focus group interview: Joyce, Bri, and Emilia ${ }^{1}$. Joyce, a professor and director of the animal welfare center at the university offering the MOOC, was the overall leader of the course, with the most visible presence within the course videos. Bri, an animal science researcher with a specialty in animal personality at a collaborating college, was the second most visible instructor, participating actively in the forums and the weekly Google Hangout synchronous meetings the team offered. The third instructor interviewed, Emilia, was the director of an online program of animal welfare at the university. The three instructors who were not able to attend the interview were Scarlett, a veterinary surgeon who worked mainly overseas in Asia; Sophie, a veterinary nurse at the college who lead the companion animal welfare week; and Hannah, an animal scientist who focused on the research for welfare of the maternal behaviour of pigs.

\section{Data Collection}

Our primary source of data were online instructor posts, which were collected within the course discussion forums. Overall, the team of six instructors composed 421 posts. We reviewed 398 instructor discussion forum posts and 23 instructor announcements. In addition, we conducted a ninety-minute focus group interview with three of the six instructors via Skype. Only three instructors replied back to the researchers' recruitment email and agreed to participate in the focus-group interview. The instructors were asked about their intentions, perspectives, and experiences in facilitating the MOOC. We used semistructured, open-ended questions that sought to understand the facilitation experiences they had as a team within the MOOC. The focus group interview was audio recorded and transcribed verbatim. Finally, we reviewed the course syllabus and instructional activities and materials provided to learners within the MOOC.

\section{Data Analysis}

A group of four researchers worked collaboratively on the data analysis, employing an interpretive qualitative approach via content analysis of the team of instructors' posts, in order to examine our research questions.

The instructor posts were all coded and categorized into the three areas: the intention to establish SP, TP, and attitudinal dissonance. Attitudinal dissonance included cognitive, affective, and behavioural

\footnotetext{
${ }^{1}$ Pseudonyms have been used for instructor names.
} 
dissonance strategies (see Appendix). We used inductive and deductive methods for establishing our coding scheme, with the majority of codes taken from previous literature (Richardson, Koehler, Besser, Caskurlu, Lim \& Mueller, 2015), but also drawing codes from the definitions of SP, TP, and dissonance for attitude change as discussed in the literature review. In addition, a few codes emerged during the data analysis (see Appendix). We analyzed posts by applying a constant comparison method (Glaser, 1965) in order to identify the key themes related to strategies for facilitating the discussions. All posts were coded at the sentence level and had various demonstrations. For example, this included descriptive sentences of how to approach an assignment in order to create a real world application of the learning, as well as such simple responses as providing a due date. Reliability was established by having three researchers coding the instructor postings independently for triangulation. We then compared the results of the coding among coders for discussion and consensus building, which allowed for $100 \%$ inter-coder agreement (Creswell, 2014).

Focus group interview data were reviewed in order to obtain a deeper level of understanding about the instructors' intentions in facilitating the discussion. The transcription was first coded to identify the big picture of the instructors' experience regarding facilitation within the MOOC. We then divided all interview data into meaningful units and compared them with the results of the previously coded discussion posts and announcements. Then, we engaged in analysis to formulate the meaningful themes from the interview data. Finally, we crosschecked our identified meaningful themes across various data sources (e.g., discussion posts, announcement posts, interview data, and course materials), and revised them until we reached agreement (Creswell, 2014). At the end, we applied member-checking in order to gauge participants for feedback and approval.

\section{Results}

The 398 instructor discussion posts were from the introduction to the course forum and weekly forums that focused on each week's topic. The 23 instructor announcements served to welcome learners, and shared weekly announcements regarding each week's topic and assignments. The codes used for analysis of the posts were based on the establishment of SP, TP, and dissonance. Within the 421 posts, a total of 4,020 coding references were found.

Table 1

Social, Teaching, and Dissonance Codes

\begin{tabular}{|l|l|l|l|}
\hline Total Coding References & \# / \% SP Codes & \# / \% TP Codes & \# / \% Dissonance Codes \\
\hline 4,020 & $1515 / 37.69 \%$ & $1461 / 36.34 \%$ & $1044 / 25.97 \%$ \\
\hline
\end{tabular}


While the most used category was SP, at 37.69 percent (see Table 1), significant use of all three categories was confirmed, with 36.34 percent of TP and 25.97 percent of Dissonance strategies found. More specifically, we identified three SP codes, four TP codes, and three Dissonance codes to be regularly used by the instructor team. Table 2 demonstrates the Top 10 of these codes. With the top code of selfdisclosure, we see the instructor team's strong emphasis on establishing an engaging and intimate atmosphere within the MOOC. With the second highest used code, clarifying, we see the instructor team's role as a supportive teacher, helping learners to successfully understand the content of the MOOC. The presence of three SP codes in the top 10 exemplifies the instructor teams' continuous and wide-ranging efforts to establish a positive culture of learning within the course (see Table 2). While strategies such as using a learner's name may require less instructor effort and also be less impactful than strategies such as self-disclosure or acknowledging student posts (Richardson, et al., 2015), the frequent use of SP codes show a consistent effort by the team to establish a strong instructor presence within the forums and the course overall. In addition, the three attitudinal dissonance codes in the top ten codes show the instructors' efforts in introducing attitudinal dissonance about the ABW topic. In the next section, we provide a more detailed explanation of the instructors' strategies in establishing SP, TP, and dissonance.

Table 2

Top 10 Codes

\begin{tabular}{|l|r|r|}
\hline Code rank / name & \# Observations & $\%$ \\
\hline 1. SP-Self-disclosure & 251 & $14.5 \%$ \\
\hline 2. TP-Clarifying & 219 & $12.6 \%$ \\
\hline 3. SP-Using name & 183 & $10.5 \%$ \\
\hline 4. TP-Directing student attention & 181 & $10.4 \%$ \\
\hline 5. SP-Greeting \& salutations & 175 & $10.1150 \%$ \\
\hline 6. Behavioural Dissonance-Discussing real world activism & 154 & $8.9 \%$ \\
\hline 7. Cognitive Dissonance-Discussing professional work practices & 150 & $8.7 \%$ \\
\hline $\begin{array}{l}\text { 8. Behavioural Dissonance-Discussing instructor authenticity and living the } \\
\text { message }\end{array}$ & 145 & $8.3 \%$ \\
\hline 9. TP-Providing tips outside course & 141 & $8.1 \%$ \\
\hline 10. TP-Connecting to content ideas & 138 & $7.9 \%$ \\
\hline TOTAL & 1737 & $100 \%$ \\
\hline
\end{tabular}

\section{Social Presence}

Research Question 1: How did MOOC instructors establish SP with intention to facilitate attitude change around the social issue of ABW?

As shown in Table 3, the SP indicators consisted of affective, cohesive, and interactive codes. Affective codes consisted of the instructor's use of self-disclosure, personal values, emotion (e.g., expressing nonverbal emotions or using emoticons), enthusiasm, and humour. Cohesive codes included greetings 
and salutations, use of participant names, encouragement, group-references, and comments on collaboration and diversity. Interactive codes contained acknowledgements, agreements/disagreements, approvals, and invitations to further discussion on the topic. Affective (41.25\%) and cohesive codes (41.85\%) represented the majority of SP codes (see Table 3). Table 4 also shows that the top five SP codes included two affective codes, two cohesive codes, and one interactive code.

Table 3

SP Codes

\begin{tabular}{|l|l|l|l|}
\hline Total SP Codes & \# / \% Affective Codes & \# / \% Cohesive Codes & \# / \% Interactive Codes \\
\hline 1515 & $625 / 41.25 \%$ & $634 / 41.85 \%$ & $256 / 16.90 \%$ \\
\hline
\end{tabular}

Table 4

Top Five SP Codes

\begin{tabular}{|l|r|}
\hline Code rank / name & $\#$ \\
\hline 1. Affective-Self-disclosure & Observations \\
\hline 2. Cohesive-Using name & 251 \\
\hline 3. Cohesive-Greeting \& salutations & 183 \\
\hline 4. Affective-Sharing emotions & 175 \\
\hline 5. Interactive-Showing approval & 122 \\
\hline
\end{tabular}

Self-disclosure had the highest frequency of SP indicators, with the use of learners' names ranking as the second highest frequency of SP codes. The third most used social codes were greetings and salutations. The fourth most common display of SP strategy was the instructors' sharing of emotions, with the instructor showing approval and acknowledging student posts ranking as the fifth most common strategy used for SP. Together, these SP indicators exhibit the instructor team's solid efforts in forming an engaging and open course culture that facilitated a global discussion on ABW. The data from the instructor team focus group interview also suggested that a facilitation choice was made to address the establishment of a positive culture of learning where people wanted to engage and talk with one another. Bri, the most visible instructor on the forums, explained her perspective on their approach of facilitating the MOOC.

So I have quite a lot of experience with Internet and online communities. I have experience moderating them, particularly video game communities. It was not that different than what I do in my spare time anyway. . . we had a high presence, a high moderator presence. . . we had an introduce yourself thread and a references thread which were started by us and people were contributing to throughout the whole five or six weeks - their first intro being me talking on the forums with a discussion post. 
The lead instructor, Joyce, shared how important it was to her to facilitate the experience of engagement among learners:

We enjoyed the discussion boards. . . the level of communication was very impressive. The discussion was very far reaching, and went further than we expected it to. The greatest thing we enjoyed. . . was seeing the relationships that allowed for real exchange of information across huge parts of the world. An example, there was an international buyer for a big meat company, and he's an animal welfare expert in that company, and he was having this wonderful conversation with a young boy of 13 from Dubai. The boy had questions about slaughtering animals. The two of them engaged in this great conversation. The two of them would not have met, never have had that conversation but through the discussion board and going through the MOOC. They engaged with each other. I think it did do all the things we wanted to do from that perspective; it got people talking and engaging and thinking about the science of animal welfare, not just their opinion and emotion.

\section{Teaching Presence}

Research Question 2: How did a MOOC instructor establish teaching presence with intention to facilitate attitude change around the social issue of ABW?

TP indicators are comprised of strategies that the instructor team used for facilitating discourse, providing direct instruction, and conducting assessment (see Table 5). Facilitating discourse included emphasizing certain topics, offering tips for success in the course, providing summaries, or directing students' attention. Direct instruction codes contained activities such as clarifying, providing examples, or sharing resources. The assessment codes included strategies such as providing formative and summative feedback within the discussion forum. Facilitating discourse represented the clear majority of codes, including $60.43 \%$ of the total TP codes, with three of the five top codes from facilitating discourse (see Table 6).

Table 5

TP Codes

\begin{tabular}{|l|l|l|l|}
\hline $\begin{array}{l}\text { Total TP } \\
\text { Codes }\end{array}$ & $\begin{array}{l}\text { \# / \% Facilitating Discourse } \\
\text { Codes }\end{array}$ & $\begin{array}{l}\text { \# / \% Direct Instruction } \\
\text { Codes }\end{array}$ & $\begin{array}{l}\text { \# / \% Assessment } \\
\text { Codes }\end{array}$ \\
\hline 1461 & $883 / 60.43 \%$ & $541 / 37.02 \%$ & $37 / 2.53 \%$ \\
\hline
\end{tabular}

Table 6

Top Five TP Codes

\begin{tabular}{|l|r|}
\hline Code rank / name & \# Observations \\
\hline 1. Direct Instruction-Clarifying & 219 \\
\hline 2. Facilitating Discourse-Directing student attention & 181 \\
\hline 3. Facilitating Discourse-Providing tips outside course & 141 \\
\hline
\end{tabular}




\begin{tabular}{|l|r|}
\hline 4. Facilitating Discourse-Connecting to content ideas & 138 \\
\hline 5. Direct Instruction-Providing examples & 133 \\
\hline
\end{tabular}

Fifteen percent of the total TP codes involved the instructor clarifying a topic or issue. These included such items as sharing expertise on the topic, details on the discussion topic, and connecting the content to the real world. Providing tips to apply outside the course was another frequently used strategy. Other frequently used direct instruction activities included providing examples and resources. Assessment codes only consisted of $2.53 \%$ of the codes, and none of the assessment codes were in the top five. This may be due to the fact the discussion activity was voluntary, and thus more conversational and informal by nature. Still, Bri talked about how she kept an eye on all forums to make sure that the discussions were on track.

From the point of view of keeping an eye on what was happening, I had to open them [discussion forums] all the time and refresh and have a quick look at where I felt from an educational perspective the comments were going off track, and I would put in a redirecting comment.

With $60 \%$ of the TP codes dedicated to facilitating discourse, the results highlight the instructors' strong desire for learners to engage in in-depth discussion with their peers as well as the instructors. The instructors found the discussion forums to be highly impactful in formulating a more informed point of view and considering multiple viewpoints. Joyce noted:

I thought the discussion forums were fascinating. . . the way people handle themselves, that is. What was interesting was just how many people came in initially with strong points of view and through discussion they would start to appreciate other people's points of view. From there they learned quite a lot about listening to others which I think was a learning outcome we hadn't anticipated.

\section{Attitudinal Dissonance}

Research Question 3: How did a MOOC instructor establish cognitive, affective, and behavioural dissonance with intention to facilitate attitude change around the social issue of ABW?

The instructor team also focused on facilitating attitude change on the topic of ABW through the introduction of cognitive, affective, and behavioural dissonance within the forums. Attitudinal dissonance was the least used among the three categories of codes with 1,044 total codes, consisting of 25.97\%, compared to 1,515 SP codes (37.69 \%) and 1,461 TP codes (36.34 \%). The strategies used for establishing cognitive dissonance included discussion of readings/ resources or instructor videos, commenting on the global context of ABW, and highlighting related professional work. Affective codes included strategies that discussed personal stories shared, documentary videos, or additional affective resources, such as images or videos within the course. Behavioural dissonance codes mostly stemmed from discussions about applications in the real world, real world activism, examples of the instructors being authentic activists, use of social media related to ABW, and future collaboration on the topic of ABW.

A majority of codes focused on creating behavioural dissonance (see Table 7), encouraging students to take real world action, such as helping them identify practical ways to be aware of the issue of animal 
welfare and act on it. Behavioural and cognitive dissonance codes were both ranked in three of the top five dissonance codes (see Table 8), with discussing real world activism being the most frequently used code.

Table 7

Dissonance Codes

\begin{tabular}{|l|l|l|l|}
\hline $\begin{array}{l}\text { Total Dissonance } \\
\text { Codes }\end{array}$ & $\begin{array}{l}\text { \# / \% Cognitive } \\
\text { Dissonance Codes }\end{array}$ & $\begin{array}{l}\text { \# / \% Affective } \\
\text { Dissonance Codes }\end{array}$ & $\begin{array}{l}\text { \# / \% Behavioural } \\
\text { Dissonance Codes }\end{array}$ \\
\hline 1044 & $366 / 35.06 \%$ & $163 / 15.61 \%$ & $515 / 49.33 \%$ \\
\hline
\end{tabular}

Both cognitive and behavioural dissonance indicators reflected their frequent use (see Table 8). Affective dissonance strategies were used significantly less at $15.61 \%$ than cognitive (35.06\%) or behavioural strategies (49.33\%) and were not represented in the top five codes within the dissonance category. The instructor team was strongly focused on creating a community of critical thinkers that were highly informed and knowledgeable about animal science and focused on the science rather than the emotions surrounding the topic. It therefore stands to reason that the strategies for establishing dissonance appeared mostly in the cognitive and behaviour categories, rather than the affective category.

Table 8

Top Five Dissonance Codes

\section{Code rank / name}

1. Behavioural Dissonance - Discussing real world activism

2. Cognitive Dissonance - Discussing professional work practices

3. Behavioural Dissonance - Discussing instructor authenticity and living the message

4. Cognitive Dissonance - Discussing global context

5. Cognitive Dissonance - Discussing instructor videos

5. Behavioural Dissonance - Discussing personal project
Observations

154

150

145

84

67

67

In the interview, Bri noted the importance of making the students aware of the instructional team's overarching key message about the critical discussion that was needed regarding ABW, and how the science was highly important in changing the lives of animals. She described a tactic they used on the discussion boards to stay focused on science and evidence rather than emotion:

We kept coming back with: you may hold that opinion, but here is the evidence we are presenting. Let's make this a critical discussion of the evidence and not an emotional discussion about how you feel about that. That has a place, but if we are going to try and change lives of these animals... 
[we have to focus on the science].

\section{Discussion}

This study examined a team of instructors and their approach to facilitating a MOOC focused on attitudinal change. In order to better understand their facilitation in the MOOC, we coded all instructor posts and course announcements. This MOOC is of significant interest, not only for its focus on attitudinal change, but also because it was being offered by a team of experienced online instructors who were wellsupported by their institution. Because their program offers an online Master's degree program in which they all teach, the instructional team was comprised of experienced online instructors. The institution had offered numerous MOOCs before and was invested in the success of those MOOCs. Furthermore, the institution supported MOOC design and development by providing resources to MOOC instructors. This included video support that allowed the team to provide documentary-style instructional videos that situated the instructors both in personal environments, such as in their homes with their pets, as well as in professional environments related to the lives of animals, such as on farms and in stables.

By examining the design approach through the CoI framework lens, we can better understand how the instructional team and students collaborated within the MOOC to support social presence, teaching presence, and, ultimately, attitudinal learning. Additionally, analyzing instructor activities by coding discussion posts and announcements allowed us to look at how the instructional team approached establishing a positive and safe space for collaboration. The highest number of codes was related to social presence, and within that category the instructional team identified self-disclosure as the most used code. Other frequent social presence codes included greeting students, addressing them by name, sharing of emotions, and communicating approval. These illustrate how, even though the course was facilitated by an instructional team that took turns engaging in the forums, significant effort was made to establish a course environment to which students could feel connected. Nearly equal numbers of examples of affective and cohesive codes were found, with both falling between 41 and $42 \%$ of SP codes. This is a significantly higher number of examples of affective codes than either of two related previous studies. For example, a recent study of twelve instructors in a Learning Design and Technology online Master's program found only $36 \%$ affective codes and $29 \%$ cohesive (Richardson, et al, 2015), while an examination of another attitudinal change MOOC, with Human Trafficking as the topic, had 25\% affective and $47 \%$ cohesive codes (Watson, Watson, Richardson, \& Loizzo, 2016). While the other MOOC focused very much on building a community of activists, which might explain the higher cohesive code percentage, this MOOC, through its team of instructors, had many more postings and numbers of codes and higher affective percentage of codes than either prior study. This may illustrate how the team sought not only to establish a community of learners, but also a community that was emotionally engaged in the course and with its instructors. It also may be due in some part to the topic of the MOOC and its particular goals. As described in the results, the instructional team was very satisfied with the quality of the course discussions and the connections that were made between some students. This reflects the findings within the attitudinal learning literature, which describes the efficacy of establishing and facilitating a collaborative environment that promotes critique for attitude change (Kamradt \& Kamradt, 1999, 
Simonson \& Maushak, 1996). Public sharing of the targeted attitude in forums and the sense that one's attitude aligns with social consensus regarding the topic has shown to help learners gain confidence in newly acquired attitudes (Festinger, 1954; Visser \& Mirabile, 2004).

Additionally, compared to social presence, a nearly equal number of teaching presence codes were identified related to facilitating discourse and direct instruction in this MOOC. These TP codes included such direct instruction strategies as providing clarification (the top SP strategy) and providing examples (the fifth ranked TP strategy) as well as facilitating discussion strategies such as directing student attention, providing tips to related to contexts external to the course, and connecting the discussion to course content. By far, the most effort was made in facilitating discussion, while limited effort was made in providing assessment, which reflects consistent findings given the decision to not focus on assessment in the course design. With over $60 \%$ of TP codes representing discussion facilitation, the instructional team was well past the related studies, including the Human Trafficking MOOC, which added up to 34.7\% (Watson, Watson, Richardson, et al., 2016) and the online Master's program study's 50\% facilitating discourse codes (Richardson, et al., 2015). This is perhaps indicative of the team's focus to be present and visibly engaged in the forum as both of the prior studies examined courses run by single instructors or a single instructor and an assistant. The team of instructors-including two who were focused on facilitating the forum throughout the course and who also overwhelmingly provided the highest number of codes (see Appendix)-sought to engage in the forums more than is likely possible in most MOOCs given the high number of students.

Direct instruction codes in this MOOC (37\%) were lower than the Human Trafficking MOOC's 54.5\% (Watson, Watson, Richardson, et al., 2016), while higher than the online Master's program study of 31\% (Richardson et al., 2015), while assessment codes (2.53\%) were much lower than the other MOOC's 10.7\% (Watson, Watson, Richardson, et al., 2016) or the 12 instructors' 19\% (Richardson et al., 2015). These differences could perhaps be representative of different instructional style and/ or a design informed by previous experiences in MOOC design and delivery that focused on providing up front high quality instructional resources (interactive instructional videos), resources, a large instructional team that allowed for greater than normal instructor forum responsiveness in a MOOC, and a conscious minimal focus on assessment. These results seem to confirm the finding that social presence can be established in a MOOC by focusing on SP in the instructional design (Kilgore \& Lowenthal, 2015).

Finally, a much lower but still significant percentage of codes represented attitudinal dissonance (nearly 26\%). Interestingly, most of these efforts focused on behavioural (49\%) and cognitive (35\%) dissonance as opposed to affective (15.6\%). This is perhaps not surprising given the team's focus on removing emotion from the equation for their learners and focusing on the science. However, it does show that all three forms of dissonance were utilized by the instructional team, which aligns with recommendations for attitudinal change instruction in the literature (Kamradt \& Kamradt, 1999). 


\section{Limitations and Future Research}

This study has several limitations. As a single qualitative case of a team of six instructors in a MOOC, the study results are limited in generalization. This provides an additional example of instructor's approaches to use social and teaching presence in an online course (Richardson et al., 2015), as well as an examination of how an online instructor approaches using these in a MOOC for attitudinal change (Watson, Watson, Richardson, et al., 2016; Watson, Loizzo, et al., 2016). However, future case studies would provide better comparisons and contrasts of the efficacy of different instructional approaches and instructor facilitation strategies, as well as how these may relate to overall instructional design choices.

In addition, this study focused on how six instructors established SP and TP for facilitating attitude change, and therefore did not take the student perspective into account. Learners' learning outcomes were also not examined. Future studies should explore the students' perspectives on the efficacy of these strategies as they would provide valuable insights.

With the limited research on the instructional design and facilitation of MOOCs, as well as attitudinal learning, this study provides insight into how the use of social presence, teaching presence, and attitudinal dissonance may inform future instructional design and facilitation of MOOCs in general and MOOCs for attitudinal change specifically.

There is a substantial need for additional research in the area for MOOC instruction and facilitation. A better understanding of how we can use the open learning platforms to facilitate attitudinal learning regarding critical social topics may grow to become more important as the MOOC offerings and enrollment continue to grow in various MOOC platforms, and the research for effective instructional design and facilitation strategies will improve the experiences that learners have within MOOCs.

\section{Acknowledgments}

We would like to thank the Animal Behaviour and Welfare MOOC instructors for their help in providing access to the course and their participation in the study.

\section{References}

Akyol, Z., \& Garrison, D. R. (2008). The development of a community of inquiry over time in an online course: Understanding the progression and integration of social, cognitive and teaching presence. Journal of Asynchronous Learning Networks, 12(3), 3-22.

Anderson, T., Rourke, L., Garrison, R., \& Archer, W. (2001). Assessing teaching presence in a computer conferencing context. Journal of Asynchronous Learning Networks, 5(2). Retrieved from http://auspace.athabascau.ca/bitstream/2149/725/1/assessing teaching_presence.pdf 
Arbaugh, J. B., \& Hwang, A. (2006). Does “teaching presence" exist in online MBA courses? The Internet and Higher Education, 9(1), 9-21.

Arbaugh, J.B. (2010). Sage, guide, both, or even more? An examination of instructor activity in online MBA courses. Computers \& Education, 55(3), 1234-1244.

Bangert, A. (2008). The influence of social presence and teaching presence on the quality of online critical inquiry. Journal of Computing in Higher Education, 2O(1), 34-61.

Bodenhausen, G. V., \& Gawronski, B. (2013). Attitude change. In D. Reisberg (Ed.), The Oxford handbook of cognitive psychology (pp. 957-969). New York, NY: Oxford University Press.

Carver, L., \& Harrison, L. M. (2013). MOOCs and democratic education. Liberal Education, 99(4). Retrieved from https://aacu.org/liberaleducation/2013/fall/carver-harrison

Clarà, M., \& Barberà, E. (2013). Learning online: massive open online courses (MOOCs), connectivism, and cultural psychology. Distance Education, 34(1), 129-136.

Coleman, G. J. (2010). Educating the Public: Information or persuasion? Journal of Veterinary Medical Education, 37(1), 74-82.

Creswell, J. W. (2014). A concise introduction to mixed methods research. Thousand Oaks, CA: Sage.

Dillahunt, T. R., Wang, B. Z., \& Teasley, S. (2014). Democratizing higher education: Exploring MOOC use among those who cannot afford a formal education. The International Review of Research in Open and Distributed Learning, 15(5). Retrieved from http://www.irrodl.org/index.php/irrodl/article/view/1841

Dole, J. A., \& Sinatra, G. M. (1998). Reconceptualizing change in the cognitive construction of knowledge. Educational psychologist, 33(2-3), 109-128.

Festinger, L. (1954). A theory of social comparison processes. Human Relations, 7,117-140.

Flynn, J. (2013). MOOCs: Disruptive innovation and the future of higher education. Christian Education Journal, 1O(1), 149-162.

Gagne, R., Briggs, L. \& Wagner, W. (1992). Principles of instructional design. Belmont: Wadsworth/Thomson Learning.

Garrison, D. R. (2007). Online community of inquiry review: Social, cognitive, and teaching presence issues. Journal of Asynchronous Learning Networks, 11(1), 61-72.

Garrison, D. R. (2011). E-Learning in the 21st century: A framework for research and practice (2nd ed.). London: Routledge/Taylor and Francis. 
Garrison, D. R., Anderson, T., \& Archer, W. (2000). Critical inquiry in a text-based environment: Computer conferencing in higher education model. The Internet and Higher Education, 2(2-3), 87-105.

Garrison, D. R., Anderson, T. \& Archer, W. (2001). Critical thinking, cognitive presence, and computer conferencing in distance education. American Journal of Distance Education, 15(1), 7-23.

Garrison, D.R. Cleveland-Innes, M. \& Fung, T. (2010). Exploring causal relationships among cognitive, social and teaching presence: Student perceptions of the Community of Inquiry framework. The Internet and Higher Education, 13(1-2), 31-36.

Glaser, B. G. (1965). The constant comparative method of qualitative analysis. Social Problems, 436-445.

Hostetter, C., \& Busch, M. (2013). Community matters: Social presence and learning outcomes. Journal of the Scholarship of Teaching and Learning, 13(1), 77-86.

Joksimović, S., Gašević, D., Kovanović, V., Riecke, B. E. and Hatala, M. (2015), Social presence in online discussions as a process predictor of academic performance. Journal of Computer Assisted Learning, 31(6). doi:10.1111/jcal.12107

Kamradt, T. F., \& Kamradt, E. J. (1999). Structured design for attitudinal instruction. In C. M. Reigeluth (Ed.), Instructional-design theories and models: A new paradigm of instructional theory, (vol. 2), Mahwah, NJ: Lawrence Erlbaum Associates.

Kanuka, H. (2011). Interaction and the online distance classroom: Do instructional methods effect the quality of interaction? Journal of Computing in Higher Education, 23, 143-156.

Kilgore, W., \& Lowenthal, P. R. (2015). The Human Element MOOC: An experiment in social presence. In R. D. Wright (Ed.), Student-teacher interaction in online learning environments (pp. 373-391). Hershey, PA: IGI Global.

Kim, W, Watson, W. R., \& Watson, S. L. (2016). Student perceptions of learning in three MOOCs: A case study of attitudinal change instruction. Educational Media International, 53(3). Retrieved from http://dx.doi.org/10.1080/09523987.2016.1236890

Kupczynski, L., Ice, P., Weisenmayer, R., \& McCluskey, F. (2010). Student perceptions of the relationship between indicators of teaching presence and success in online courses. Journal of Interactive Online Learning, 9(1), 23-43.

Liyanagunawardena, T. R., Adams, A. A., \& Williams, S. A. (2013). MOOCs: A systematic study of the published literature 2008-2012. The International Review of Research in Open and Distributed Learning, 14(3), 202-227.

Morris, T.A. (2011). Exploring community college student perceptions of online learning. International Journal of Instructional Technology \& Distance Learning, 8(6). 
Mykota, D., \& Duncan, R. (2007). Learner characteristics as predictors of online social presence. Canadian Journal of Education, 30(1), 157-170.

Richardson, J.C., Koehler, A., Besser, E., Caskurlu, S., Lim, J., \& Mueller, C. (2015). Conceptualizing and investigating instructor presence in online learning environments. International Review of Research in Open and Distributed Learning, 16(3), 256-297.

Richardson, J.C., \& Swan, K. (2003). Examining social presence in online courses in relation to students' perceived learning and satisfaction. Journal of Asynchronous Learning Networks, 7(1), 68-88.

Rodriguez, C. O. (2012). MOOCs and the AI-Stanford like courses: Two successful and distinct course formats for massive open online courses. European Journal of Open, Distance and E-Learning. Retrieved from http:/ $/$ www.eurodl.org/?p=archives\&year $=2012 \&$ halfyear $=2 \&$ article $=516$

Shea, P., Li, C. S., \& Pickett, A. (2006). A study of teaching presence and student sense of learning community in fully online and web-enhanced college courses. The Internet and Higher Education, 9(3), 175-190.

Simonson, M. R. (1979). Designing instruction for attitudinal outcomes. Journal of Instructional Development, 2(3), 15-19.

Simonson, M., \& Maushak, N. (1996). Instructional technology and attitude change. In Jonassen (Ed.), Handbook of research for educational communications and technology (pp. 984-1016). Mayway, NJ: Lawrence Erlbaum Associates.

Sinatra, G. M., Kardash, C. M., Taasoobshirazi, G., \& Lombardi, D. (2012). Promoting attitude change and expressed willingness to take action toward climate change in college students. Instructional Science, $40(1), 1-17$.

Swan, K., Garrison, D. R., \& Richardson, J. (2009). A constructivist approach to online learning: The Community of Inquiry framework. In C. R. Payne (Ed.), Information technology and constructivism in higher education: Progressive learning frameworks (pp. 43-57), Hershey. PA: IGI Global.

Swan, K., Shea, P., Richardson, J.C., Ice, P., Garrison, D. R., Cleveland-Innes, M., \& Arbaugh, J.B. (2008). Validating a measurement tool of presence in online communities of inquiry. E-mentor, 2(24), 112.

Visser, P. S., \& Mirabile, R. R. (2004). Attitudes in the social context: The impact of social network composition on individual-level attitude strength. Journal of Personality and Social Psychology, 87, 779 -795.

Watson, S. L., \& Kim, W. (2016). Enrolment purposes, instructional activities, and perceptions of attitudinal learning in a human trafficking MOOC. Open Learning: The Journal of Open, Distance and e-Learning, 31(3), 273-287. 
Watson, S. L., Loizzo, J., Watson, W. R., Mueller, C., Lim, J., \& Ertmer, P. (2016). Instructional design, facilitation, and perceived learning gains: An exploratory case study of a human trafficking MOOC for attitudinal change. Educational Technology Research and Development, 64(6), 1273-1300

Watson, S. L., Watson, W. R., Richardson, J. \& Loizzo, J. (2016). Instructor's use of social presence, teaching presence and attitudinal dissonance: A case study of an attitudinal change MOOC. The International Review of Research in Open and Distributed Learning. 17(3).

Watson, W. R., Kim. W., \& Watson, S. L. (2016). Learning outcomes of a MOOC designed for attitudinal change: A case study of an animal behavior and welfare MOOC. Computers and Education, 96, 83-93.

Wexler, E. (2015, October 19). MOOCs are still rising, at least in numbers. The Chronicle of Higher Education. Retrieved from: http://chronicle.com/blogs/wiredcampus/moocs-are-still-rising-atleast-in-numbers/57527

Zimbardo, P. G., \& Leippe, M. R. (1991). The psychology of attitude change and social influence. New York, NY: McGraw-Hill Book Company. 


\section{Appendix}

\begin{tabular}{|c|c|c|c|c|c|c|c|c|}
\hline & Emi & Bri & Scarlett & Joyce & Hannah & Sophie & Announcements & Total \\
\hline \multicolumn{9}{|l|}{ SOCIAL PRESENCE } \\
\hline Affective & 140 & $\mathbf{3 5 7}$ & 36 & 23 & 10 & 9 & 50 & 625 \\
\hline Af- Self disclosure & 60 & 139 & 21 & 9 & 2 & 3 & 17 & 251 \\
\hline Af- Sharing values & 18 & 51 & 6 & 3 & 2 & 2 & 7 & 89 \\
\hline Af- Sharing emotions & 35 & 64 & 4 & 5 & 3 & 3 & 8 & 122 \\
\hline Af- Sharing enthusiasm & 10 & 55 & 5 & 6 & 2 & 1 & 17 & 96 \\
\hline Af- Sharing humor & 17 & 48 & o & o & 1 & o & 1 & 67 \\
\hline Cohesive & 209 & $\mathbf{2 8 5}$ & 40 & 12 & 8 & 6 & 74 & 634 \\
\hline Co- Greeting \& salutations & 77 & 52 & 16 & 3 & 2 & 2 & 23 & 175 \\
\hline Co- Using name & 73 & 89 & 15 & 4 & 2 & 2 & $\mathrm{o}$ & 183 \\
\hline Co- Encouraging & 25 & 53 & 2 & 2 & 2 & 1 & 6 & 91 \\
\hline Co- Using group reference & 21 & 25 & 1 & 1 & o & 1 & 22 & 71 \\
\hline $\begin{array}{l}\text { Co- Encouraging } \\
\text { collaboration }\end{array}$ & 4 & 32 & 4 & o & 1 & o & 14 & 55 \\
\hline Co- Encouraging diversity & 9 & 34 & 2 & 2 & 1 & o & 9 & 57 \\
\hline Interactive & 85 & 121 & 22 & 8 & 5 & $\mathbf{1}$ & 14 & 256 \\
\hline $\begin{array}{l}\text { IN- } \\
\text { Repeat/Acknowledgement }\end{array}$ & 14 & 6 & 4 & 2 & 1 & o & 3 & 30 \\
\hline
\end{tabular}




\begin{tabular}{|c|c|c|c|c|c|c|c|c|}
\hline IN- Agreement/Disagreement & 29 & 43 & 2 & 1 & $\mathrm{O}$ & $\mathrm{O}$ & 1 & 76 \\
\hline IN- Showing approval & 32 & 54 & 14 & 2 & 3 & 1 & 1 & 107 \\
\hline IN- Extending invitation & 10 & 18 & 2 & 3 & 1 & $\mathrm{o}$ & 9 & 43 \\
\hline $\begin{array}{l}\text { TOTAL SOCIAL PRESENCE } \\
\text { INDICATORS }\end{array}$ & $\begin{array}{l}\mathbf{4 3 4} \\
\mathbf{3 8 . 3} \%\end{array}$ & $\begin{array}{l}763 \\
\mathbf{3 8 . 7} \\
\%\end{array}$ & $\begin{array}{l}98 \\
\mathbf{3 0 . 8} \%\end{array}$ & $\begin{array}{l}43 \\
36.1 \%\end{array}$ & $\begin{array}{l}23 \\
29.1 \%\end{array}$ & $\begin{array}{l}16 \\
\mathbf{3 6 . 3} \%\end{array}$ & $\begin{array}{l}138 \\
\mathbf{3 8 . 2 \%}\end{array}$ & $\begin{array}{l}\mathbf{1 5 1 5} \\
\mathbf{3 7 . 6 \%}\end{array}$ \\
\hline Facilitating Discourse & 219 & 443 & 96 & $\mathbf{2 3}$ & 24 & 10 & 68 & 883 \\
\hline FD- Emphasizing & 17 & 45 & 14 & 4 & 3 & 2 & 11 & 96 \\
\hline $\begin{array}{l}\text { FD- Directing student } \\
\text { attention }\end{array}$ & 29 & 97 & 20 & 6 & 5 & 2 & 22 & 181 \\
\hline FD- Providing tips & 36 & 34 & 9 & 2 & $\mathrm{O}$ & $\mathrm{o}$ & 4 & 85 \\
\hline FD- Summarizing & 18 & 37 & 10 & 1 & 3 & 1 & o & 70 \\
\hline $\begin{array}{l}\text { FD- Providing tips outside } \\
\text { course }\end{array}$ & 36 & 71 & 12 & 4 & 4 & 3 & 11 & 141 \\
\hline FD- Prompting & 3 & 19 & 2 & $\mathrm{o}$ & 1 & o & 7 & 32 \\
\hline FD- Asking for clarification & 3 & 9 & $\mathrm{O}$ & $\mathrm{O}$ & $\mathrm{O}$ & $\mathrm{O}$ & $\mathrm{O}$ & 12 \\
\hline $\begin{array}{l}\text { FD- Connecting to content } \\
\text { ideas }\end{array}$ & 36 & 61 & 20 & 4 & 5 & 1 & 11 & 138 \\
\hline $\begin{array}{l}\text { FD- Providing alternative } \\
\text { viewpoint }\end{array}$ & 41 & 70 & 9 & 2 & 3 & 1 & 2 & 128 \\
\hline Direct Instruction & 171 & $\mathbf{2 5 7}$ & 51 & 16 & 8 & 7 & $\mathbf{3 1}$ & 541 \\
\hline DI- Direct questioning & 5 & 12 & $\mathrm{O}$ & $\mathrm{O}$ & $\mathrm{O}$ & $\mathrm{O}$ & $\mathrm{O}$ & 17 \\
\hline DI- Clarifying & 68 & 106 & 18 & 6 & 5 & 3 & 13 & 219 \\
\hline
\end{tabular}




\begin{tabular}{|c|c|c|c|c|c|c|c|c|}
\hline DI- Providing examples & 45 & 60 & 16 & 5 & 3 & 1 & 3 & 133 \\
\hline DI- Providing demonstration & 12 & 39 & 6 & 3 & $\mathrm{O}$ & 3 & 7 & 70 \\
\hline DI- Providing resources & 41 & 40 & 11 & 2 & $\mathrm{O}$ & $\mathrm{O}$ & 8 & 102 \\
\hline Assessment & 11 & 16 & $\mathbf{1}$ & $\mathbf{1}$ & $\mathbf{o}$ & $\mathbf{o}$ & 8 & 37 \\
\hline $\begin{array}{l}\text { As- Formative feedback on } \\
\text { discussion }\end{array}$ & 11 & 10 & 1 & 1 & $\mathrm{O}$ & $\mathrm{O}$ & 3 & 26 \\
\hline $\begin{array}{l}\text { As- Summative feedback on } \\
\text { discussion }\end{array}$ & 0 & 1 & $\mathrm{O}$ & $\mathrm{O}$ & 0 & $\mathrm{O}$ & 1 & 2 \\
\hline $\begin{array}{l}\text { As- Formative feedback on } \\
\text { other assignments }\end{array}$ & $\mathrm{O}$ & 2 & $\mathrm{O}$ & $\mathrm{O}$ & 0 & $\mathrm{O}$ & 2 & 4 \\
\hline $\begin{array}{l}\text { As- Summative feedback on } \\
\text { other assignments }\end{array}$ & $\mathrm{O}$ & 3 & $\mathrm{O}$ & $\mathrm{O}$ & 0 & $\mathrm{O}$ & 2 & 5 \\
\hline $\begin{array}{l}\text { TOTAL TEACHING } \\
\text { PRESENCE INDICATORS }\end{array}$ & $\begin{array}{l}401 \\
35 \cdot 4 \%\end{array}$ & $\begin{array}{l}716 \\
36.4 \\
\%\end{array}$ & $\begin{array}{l}148 \\
46.5 \%\end{array}$ & $\begin{array}{l}40 \\
33.6 \%\end{array}$ & $\begin{array}{l}32 \\
40.5 \%\end{array}$ & $\begin{array}{l}17 \\
\mathbf{3 8 . 6 \%}\end{array}$ & $\begin{array}{l}107 \\
29.6 \%\end{array}$ & $\begin{array}{l}1461 \\
36.34 \%\end{array}$ \\
\hline Cognitive Dissonance & 100 & 173 & $\mathbf{2 8}$ & 12 & 7 & $\mathbf{3}$ & 43 & 366 \\
\hline $\begin{array}{l}\text { CD- Discussing readings \& } \\
\text { resources }\end{array}$ & 0 & 52 & $\mathrm{O}$ & 2 & 0 & 1 & 10 & 65 \\
\hline $\begin{array}{l}\text { CD- Discussing instructor } \\
\text { videos }\end{array}$ & 11 & 33 & 1 & 4 & 0 & 1 & 17 & 67 \\
\hline CD- Discussing global context & 40 & 29 & 8 & 3 & 2 & $\mathrm{O}$ & 2 & 84 \\
\hline $\begin{array}{l}\text { CD- Discussing professional } \\
\text { work practices }\end{array}$ & 49 & 59 & 19 & 3 & 5 & 1 & 14 & 150 \\
\hline Affective Dissonance & 40 & 94 & 13 & 6 & $\mathbf{1}$ & 2 & 7 & 163 \\
\hline
\end{tabular}




\begin{tabular}{|c|c|c|c|c|c|c|c|c|}
\hline $\begin{array}{l}\text { AD- Discussing personal } \\
\text { stories in course }\end{array}$ & 6 & 35 & 2 & 4 & $\mathrm{O}$ & 2 & 0 & 49 \\
\hline $\begin{array}{l}\text { AD- Discussing undercover or } \\
\text { documentary videos }\end{array}$ & 1 & 6 & $\mathrm{O}$ & $\mathrm{O}$ & $\mathrm{O}$ & $\mathrm{O}$ & $\mathrm{O}$ & 7 \\
\hline $\begin{array}{l}\text { AD- Discussing affective } \\
\text { resources }\end{array}$ & 33 & 53 & 11 & 2 & 1 & o & 7 & 107 \\
\hline Behavioural Dissonance & $\mathbf{1 5 7}$ & 221 & $\mathbf{3 1}$ & 18 & 16 & 6 & 66 & $\mathbf{5 1 5}$ \\
\hline $\begin{array}{l}\text { BD- Discussing personal } \\
\text { projects }\end{array}$ & 35 & 24 & 1 & 4 & 2 & 1 & $\mathrm{O}$ & 67 \\
\hline $\begin{array}{l}\text { BD- Discussing personal } \\
\text { application to real world }\end{array}$ & 21 & 23 & 1 & 5 & 3 & 2 & $\mathrm{O}$ & 55 \\
\hline $\begin{array}{l}\text { BD- Discussing real world } \\
\text { activism }\end{array}$ & 50 & 58 & 17 & 3 & 5 & 1 & 20 & 154 \\
\hline $\begin{array}{l}\text { BD- Discussing instructor } \\
\text { authenticity and living the } \\
\text { message }\end{array}$ & 29 & 78 & 12 & 5 & 5 & 2 & 14 & 145 \\
\hline BD- Discussing social media & 8 & 22 & o & 1 & o & o & 14 & 45 \\
\hline $\begin{array}{l}\text { BD- Discussing future } \\
\text { collaboration }\end{array}$ & 14 & 16 & $\mathrm{O}$ & $\mathrm{O}$ & 1 & $\mathrm{O}$ & 18 & 49 \\
\hline $\begin{array}{l}\text { TOTAL DISSONANCE } \\
\text { INDICATORS }\end{array}$ & $\begin{array}{l}297 \\
\mathbf{2 6 . 2 \%}\end{array}$ & $\begin{array}{l}488 \\
24.8 \\
\%\end{array}$ & $\begin{array}{l}72 \\
22.6 \%\end{array}$ & $\begin{array}{l}36 \\
\mathbf{3 0 . 2 \%}\end{array}$ & $\begin{array}{l}24 \\
\mathbf{3 0 . 3} \%\end{array}$ & $\begin{array}{l}11 \\
25 \%\end{array}$ & $\begin{array}{l}\mathbf{1 1 6} \\
\mathbf{3 2 . 1} \%\end{array}$ & $\begin{array}{l}1044 \\
25 \cdot 9 \%\end{array}$ \\
\hline TOTAL INDICATORS & $\begin{array}{l}1132 \\
28.1 \%\end{array}$ & $\begin{array}{l}1967 \\
48.9 \\
\%\end{array}$ & $\begin{array}{l}\mathbf{3 1 8} \\
7 \cdot 9 \%\end{array}$ & $\begin{array}{l}119 \\
2.9 \%\end{array}$ & $\begin{array}{l}79 \\
1.9 \%\end{array}$ & $\begin{array}{l}44 \\
1 \%\end{array}$ & $\begin{array}{l}\mathbf{3 6 1} \\
\mathbf{8 . 9} \%\end{array}$ & 4020 \\
\hline
\end{tabular}


Athabasca

University

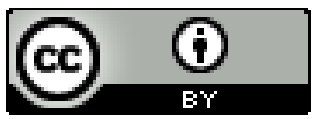

